\title{
A PRELIMINARY STUDY ON THE ANTIOXIDANT AND ANTI- INFLAMMATORY ACTIVITIES OF OPOPANAX HISPIDUS
}

\author{
OPOPANAX HISPIDUS'UN ANTIOKSIDAN VE ANTI-INNFLAMATUAR AKTIVITTELERI \\ ÜZERINE BIR ÖN ÇALIŞMA
}

\section{Safa GÜMÜŞOK ${ }^{*}$ (D), Sezen YILMAZ SARIALTIN² ${ }^{2}$, Tülay ÇOBAN² ${ }^{(D)}$, Ceyda Sibel KILIÇ ${ }^{1}$ (D)}

${ }^{1}$ Department of Pharmaceutical Botany, Faculty of Pharmacy, Ankara University, Tandoğan 06560, Ankara, Turkey

${ }^{2}$ Department of Pharmaceutical Toxicology, Faculty of Pharmacy, Ankara University, Tandoğan 06560, Ankara, Turkey

\begin{abstract}
Objective: Opopanax W. Koch genus is included in Apiaceae family. The genus can be distinguishable with its compound basal leaves, glabrous fruits, yellow flowers, tall stem with glochidate and stellate hairs. It is known with the name "Hercules' all-heal" throughout the world. It was used for the treatment of epilepsy, infertility in women, hemorrhoids and paralysis traditionally. This present research was designed to assess in vitro antioxidant and anti-inflammatory activity of Opopanax hispidus (Friv.) Griseb.

Material and Method: Methanol extracts were prepared from the aerial parts and flowers of the plants. Their antioxidant activities were analyzed through a number of chemical assays: 2,2'-azino-bis(3ethylbenzothiazoline-6-sulphonic acid) (ABTS) and 2,2-diphenyl-l-picrylhydrazyl (DPPH) free radical scavenging assays. Anti-inflammatory activities of the extracts were compared and evaluated using human red blood cell membrane stability testing.

Result and Discussion: Aerial parts exhibited stronger ABTS and DPPH free radical scavenging activities than flowers. Howver, flowers were found to be more active than aerial parts in terms of anti-inflammatory effects $\left(I C_{50}=3,32 \mathrm{mg} / \mathrm{ml}\right.$ and $4,75 \mathrm{mg} / \mathrm{ml}$; respectively). These data suggest that flowers and aerial parts of Opopanax hispidus exhibited antioxidant and anti-inflammatory effects. More research studies are necessary to determine the active ingredients in charge of this activity.

Keywords: ABTS, anti-inflammatory, antioxidant, DPPH, Opopanax hispidus ÖZ
\end{abstract}

\footnotetext{
* Corresponding Author/Sorumlu Yazar: Safa Gümüşok e-mail / e-posta: safagumusok@ gmail.com, Phone / Tel: +905449674616
} 
Amaç: Opopanax W. Koch cinsi, Apiaceae familyasında yer alır. Cins, bileşik bazal yaprakları, tüysüz meyveleri, sarı çiçekleri, gloşidat ve yıldızs tüyleri olan uzun gövdesi ile ayırt edilebilir. Dünya çapında "Herkül'ün her şeyi iyileştireni" adıyla bilinir. Halk arasında epilepsi, kadınlarda kısırlı, hemoroid ve felç tedavisi için kullanılır. Bu araştırma, Opopanax hispidus (Friv.) Griseb'in in vitro antioksidan ve antiinflamatuar aktivitesini değerlendirmek için tasarlanmıştır.

Gereç ve Yöntem: Bitkinin toprak üstü kısımlarından ve çiçeklerinden metanol ekstreleri hazırlandl. Antioksidan aktiviteleri bir dizi kimyasal deneyle analiz edildi: 2,2'-azino-bis-3-etilbenzotiazolin- 6-sülfonik asit (ABTS) ve 2,2-difenil-l-pikrilhidrazil (DPPH) serbest radikal süpürme deneyleri. Ekstrelerin antiinflamatuar aktiviteleri insan kırmızı kan hücresi membran stabilite testi kullanılarak karşılaştırıldı ve değerlendirildi.

Sonuç ve Tartışma: Toprak üstü kısımları, çiçeklerden daha güçlü ABTS ve DPPH serbest radikal temizleme aktiviteleri sergiledi. Ancak anti-inflamatuvar etki açısından çiçeklerin toprak üstü kisımlardan daha aktif olduğu bulundu (IC50=3,32 mg/ml ve 4,75 mg/ml, siraslyla). Bu veriler, Opopanax hispidus'un çiçek ve toprak üstü kısımlarının antioksidan ve anti-inflamatuar etkiler sergilediğini göstermektedir. Bu aktiviteden sorumlu aktif içerikleri belirlemek için daha fazla araştırma çalışması gereklidir.

Anahtar Kelimeler: ABTS, anti-inflamatuvar, anti-oksidan, DPPH, Opopanax hispidus

\section{INTRODUCTION}

Apiaceae is known as parsley or carrot family having more than 300 genera with not less than 3000 species. They grow naturally in the northern hemisphere [1]. This large family attracts attention due to its diverse secondary metabolites, and also its great economic and medical value [2].

Opopanax species are known with the names Kaymakotu, Kaymacık and Kirkozar in Turkey [3] and with the name "Hercules' all-heal" in the world. English name of genus give us a hint about its usage. When etimologically examined the word "Opopanax", it is derived from the words "opos" and "panax". The word "opos" means usare (vegetable juice) and the word "panax" (panacea) means allhealing, universal remedy [4].

Opopanax W. Koch, a genus of the Apiaceae family has 4 species: Opopanax hispidus (Friv.) Gris., Opopanax chironium (L.) W. Koch, Opopanax persicus Boiss., and Opopanax siifolius (Boiss. \& Heldr.) Menemen. Opopanax species are traditionally being used both in Turkey and throughout the world due to their medical effects. Gum derived from $O$. chironium's stem is used in the treatment of epilepsy among people in Iran [5]. O. chironium was used in the treatment of epilepsy during the Renaissance period [6]. As a result of an excavation conducted in Cairo, O. chironium was found that this species was used in colic and colds, eye diseases, convulsions, tetany and to strengthen erections in the Middle Ages [7]. It has been reported that the ointment prepared with the mixture of fat-gum-resin (oleogumresin) obtained from $O$. chironium used against all cancers in traditional Islamic medicine [8]. $O$. chironium has been used for antinociceptive against headache, joint pain and rhematoid arthritis, as well as, diuretic in traditional Iranian medicine [9]. O. hispidus is consumed as food in and around Kazdağ [10]. In a study conducted in the Ilıcalı region of Erzurum, it was reported that the fresh bodies of $O$. hispidus were eaten and thus used to treat female infertility [11]. In the study conducted in Eğirdir, powdered leaves of $O$. hispidus were found to be used in the treatment of hemorrhoids by eating [12]. 
In Turkey, O. hispidus is located in a group of plants known as "Mayas1l otu" and has been reported to be used in the treatment of hemorrhoids [13]. In "Dynameron" writting around $10^{\text {th }}-11^{\text {th }}$ centuries, $O$. hispidus was reported to be used as an antidote [14]. It has been reported that the stem, leaf and inflorescence of $O$. hispidus are utilized as antiseptic by smoking [15]. There is information about the resin obtained from $O$. persicus is used to treat paralysis from nasal way, but no more details are given [16]. There is no information about $O$. siifolius (Crenosciadium siifolium).

Since these species have been used for antinociceptive effects against headache and joint pain, in this study we aimed to investigate antioxidant and anti-inflammatory activities of $O$. hispidus that grows naturally in Turkey.

\section{MATERIAL AND METHOD}

\section{Plant Samples}

Plant samples were gathered from the following locality and voucher specimens are kept in AEF (Herbarium of Ankara University, Faculty of Pharmacy):

C3: Akseki, Sadıklar Village entrance, near the fields, 978 m, H. Duman, C.S. Kılıç, 20/6/2016.

O. hispidus' aerial parts and flowers, first macerated with methanol for 8 hours 3 times, were evaporated with a rotary evaporator (Heidolph WB 2000\&VV2000).

\section{Chemicals}

Trolox, acetylsalicylic acid (ASA), butylated hydroxytoluene (BHT), 2,2-diphenyl-1picrylhydrazyl (DPPH), 2,2' - azino bis-(3-ethylbenzothiazoline-6-sulphonic acid) (ABTS) were bought from Sigma-Aldrich. Dimethyl sulfoxide (DMSO), methanol and the other solvents were bought from Merck.

\section{Antioxidant Activity}

\section{ABTS $^{+}{ }^{+}$Free Radical Scavenging Activity}

ABTS radical cation decolorization assay was utilized to measure the total antioxidant activity of the samples [17]. ABTS was prepared by the reaction of $7 \mathrm{mM}$ ABTS+ aqueous solution with $2.45 \mathrm{mM}$ potassium persulfate. The experiment mixture was left to wait for a night (12 to $16 \mathrm{~h}$ ) in the dark with a temperature of $25^{\circ} \mathrm{C}$ before usage. To assign an absorbance value of $0.700 \pm 0.02$ at $734 \mathrm{~nm}$, the resultant strongly-colored ABTS radical cation was diluted with ethyl alcohol, $\mathrm{pH}$ 7.4. The compound was diluted $100 \mathrm{x}$ with the ABTS solution to a total volume of $1 \mathrm{ml}$. After addition, the experiment mixture was left to wait $6 \mathrm{~min}$ at room temperature. Then the absorbance was measured spectrophotometrically at 734 $\mathrm{nm}$ and inhibition percentage was computed. The assay was conducted three times for one extract. On a regular time basis (every five days) fresh stocks of $\mathrm{ABTS}^{\cdot+}$ solution were made available for avoiding self-degradation of the radical. Trolox, that is the water-soluble $\alpha$-tocopherol analogue, was utilized as a standard. The findings were presented as radical scavenging activity percentage (\%) of the ABTS, 
defined by the below formula: $\left[\left(\mathrm{A}_{\mathrm{o}}-\mathrm{A}_{\mathrm{s}}\right) / \mathrm{A}_{\mathrm{o}}\right] \times 100$; which is $\mathrm{A}_{\mathrm{o}}$ means the absorbance of the control and $\mathrm{A}_{\mathrm{s}}$ is the absorbance with the sample or standard. For each plant extract and standard, half-maximal inhibitory concentration $\left(\mathrm{IC}_{50}\right)$ values were figured from a calibration curve.

\section{DPPH* Free Radical Scavenging Activity}

The DPPH free radical scavenging activities of the plant methanolic extracts were assessed by their capacity to decolorize the stable radical DPPH [18]. Various concentrations of the extracts and $100 \mu \mathrm{M}$ DPPH in methanol constituted the reaction mixture. The mixture was first shaken, then left to wait in dark for half an hour at the aforementioned temperature $\left(25^{\circ} \mathrm{C}\right)$. Then at $517 \mathrm{~nm}$, the absorbance was measured and free radical scavenging activity was computed as the percentage of radical reduction. The absorbance of the prepared solution was adapted to $0.700 \pm 0.02$ at $517 \mathrm{~nm}$. BHT was chosen as a reference compound. Each experiment was conducted in triplicate. Percentage of DPPH radical scavenging activity was computed by the below formula; $\left[\left(\mathrm{A}_{o}-A_{s}\right) / A_{o}\right] \times 100$, which is $A_{o}$ means the absorbance of the control and $\mathrm{A}_{\mathrm{s}}$ is the absorbance with the sample or standard. $\mathrm{IC}_{50}$ values were calculated from a calibration curve for each plant extract and standard compound.

\section{Anti-inflammatory Activity (*)}

\section{Preparation of Human Red Blood Cells Suspension}

A healthy human volunteer without a record of anti-inflammatory or steroidal drug use for the past 2 weeks before the experiment provided fresh whole human blood which was later transmitted to centrifuge tubes. The tubes were centrifuged for $10 \mathrm{~min}$ at $3000 \mathrm{rpm}$. The appropriate volume of sterile isosaline $(0.85 \%, \mathrm{pH} 7.2)$ was used to wash the packed cells. The blood volume was measured and remade as $10 \% \mathrm{v} / \mathrm{v}$ suspension with isosaline $[19 ; 20]$.

\section{Heat-Induced Hemolysis}

The human erythrocyte hemolysis assay which is induced by heat evaluated membrane stabilizing activity of the samples, using previously described methods with slight modifications [19;20]. Test samples (methanolic extracts) and $10 \%$ red blood cell suspension constituted the experiment mixture. The only solvent was used as a negative control. Each centrifuge tube including the experiment mixture was incubated in a water bath for half an hour at $56^{\circ} \mathrm{C}$. At the end of the incubation period, the centrifuge tubes were left for cooling under running water. The available mixture was centrifuged for 5 mins at $2500 \mathrm{rpm}$, then the supernatant absorbance was measured at $560 \mathrm{~nm}$. This experiment was carried out three times for each sample. ASA was utilized as the reference drug. Percentage of protection was computed by the below formula; $100-\left[\left(\mathrm{A}_{s} / \mathrm{A}_{\mathrm{o}}\right) \times 100\right]$, which is $\mathrm{A}_{\mathrm{o}}$ means the absorbance of the control and $A_{s}$ is the absorbance with the sample or standard. The results were represented as $\mathrm{IC}_{50}$ for each plant extract and the standard compound. 


\section{Statistical Analysis}

All of the experiments were conducted three times and the findings were displayed as mean $\mathrm{IC}_{50} \pm \mathrm{SD}$. IBM SPSS Version 25.0 was used to carry out statistical analyses, namely one-way analysis of variance (ANOVA) and post hoc Tukey test with 95\% confidence level for normally distributed groups. The results, which were accepted as statistically significant, were p-values less than 0.05 .

\section{RESULT AND DISCUSSION}

\section{Antioxidant Activity}

\section{ABTS $^{\cdot+}$ Free Radical Scavenging Activity}

ABTS free radical scavenging activities of the flowers and aerial parts of $O$. hispidus and the reference compound were presented in Table 1. Trolox was found more active than the extracts ( $\mathrm{p}=0.0001$ ). The maximum antioxidant capacity was detected for aerial parts by ABTS free radical scavenging assay with an $\mathrm{IC}_{50}$ value of $0,33 \pm 0,02 \mathrm{mg} / \mathrm{ml}$. Flowers showed lower ABTS scavenging activity than aerial parts $\left(\mathrm{IC}_{50}=0,40 \pm 0,02 \mathrm{mg} / \mathrm{ml}\right)$.

Table 1. ABTS free radical scavenging activity of flowers and aerial parts of $O$. hispidus

\begin{tabular}{|c|c|}
\hline Plant extract & $\begin{array}{c}\text { IC50 }(\mathbf{m g} / \mathbf{m l}) \\
\text { Mean } \pm \text { SD }\end{array}$ \\
\hline Flower & $0,3958 \pm 0,018$ \\
\hline Aerial parts & $0,3245 \pm 0,016$ \\
\hline Trolox & $0,0150 \pm 0,001$ \\
\hline
\end{tabular}

\section{DPPH* Free Radical Scavenging Activity}

DPPH free radical scavenging activities of the flowers and aerial parts of $O$. hispidus and the reference compound were presented in Table 2. BHT was found more active than the extracts ( $\mathrm{p}=0.0001$ ). Similar to the findings of previous activity (ABTS), the highest antioxidant potential was detected for aerial parts by DPPH free radical scavenging assay with an $\mathrm{IC}_{50}$ value of $0,50 \pm 0,01 \mathrm{mg} / \mathrm{ml}$. Flowers showed lower DPPH scavenging activity than aerial parts $\left(\mathrm{IC}_{50}=0,54 \pm 0,01 \mathrm{mg} / \mathrm{ml}\right)$.

Table 2. DPPH free radical scavenging activity of flowers and aerial parts of $O$. hispidus

\begin{tabular}{|c|c|}
\hline Plant extract & $\begin{array}{c}\text { IC50 }(\mathbf{m g} / \mathbf{m l}) \\
\text { Mean } \pm \text { SD }\end{array}$ \\
\hline Flower & $0,5405 \pm 0,0127$ \\
\hline Aerial parts & $0,5022 \pm 0,0075$ \\
\hline BHT & $0,0188 \pm 0,0004$ \\
\hline
\end{tabular}




\section{Anti-inflammatory Activity}

\section{Human Red Blood Cell Membrane Stabilizing Activity}

The cell membrane stabilizing activities of flowers and herbs of $O$. hispidus were presented in Table 3. Contrary to the results of ABTS and DPPH free radical scavenging activities, the maximum membrane stabilization activity was detected for methanol extracts of flowers with an $\mathrm{IC}_{50}$ value of $3,32 \pm 0,03 \mathrm{mg} / \mathrm{ml}$. Aerial parts exhibited lower membrane stabilizing activity than flowers with $\mathrm{IC}_{50}$ values of $4,75 \pm 0,003 \mathrm{mg} / \mathrm{ml}$. Flowers of $O$. hispidus are more effective than aerial parts of $O$. hispidus. ASA was more effective on that activity than the extracts significantly ( $\mathrm{p}=0.0001)$.

Table 3. The cell membrane stabilizing activity of flower and herbs of $O$. hispidus

\begin{tabular}{|c|c|}
\hline Plant extract & $\begin{array}{c}\text { IC50 }(\mathbf{m g} / \mathbf{m l}) \\
\text { Mean } \pm \text { SD }\end{array}$ \\
\hline Flower & $3,3177 \pm 0,0255$ \\
\hline Aerial parts & $4,7533 \pm 0,0034$ \\
\hline ASA & $0,2910 \pm 0,008$ \\
\hline
\end{tabular}

Opopanax genus has been used in traditional medicine for numerous reasons. In previous studies for methanol extracts of aerial parts of $O$. hispidus, antioxidant capacity was found as follows: ABTS: $0.08 \pm 0.032 \mathrm{mmol}$ Trolox equivalent $\mathrm{g}^{-1}$ extract [21]. Matejić et al reported that methanolic extracts of inflorescences of Opopanax hispidus showed the highest scavenging activities on DPPH and ABTS free radicals compared to aerial parts and fruits $\left(\mathrm{IC}_{50}=1.157 \mathrm{mg} / \mathrm{mL}\right.$ and $3.14 \pm 0.006 \mathrm{Vit} \mathrm{C} / \mathrm{g}$, respectively) [22]. Similarly, the greatest total phenolic $(89.95 \pm 0.005 \mathrm{mg} \mathrm{GA} / \mathrm{g})$ and total flavonoid content $(24.06$ $\pm 0.004 \mathrm{mg} \mathrm{Qu} / \mathrm{g}$ ) was found in methanol extracts of inflorescences parts [21]. In another study, radical scavenging potentials of the ethanol extracts of aerial parts of $O$. hispidus were found $88.27 \pm 0.45 \mathrm{mg}$ Trolox equivalent/g extract for DPPH and $138.07 \pm 1.48 \mathrm{mg}$ Trolox equivalent $/ \mathrm{g}$ extract for ABTS [23].

We examined radical scavenging and erythrocyte membrane stabilization capacities of different parts of $O$. hispidus. To our knowledge, this article is the first report to showing the anti-inflammatory capacity of this plant. ABTS and DPPH radical scavenging activities were found higher for aerial parts than flowers, but not a serious margin. Naturally-occurring plant pigments, phenolic compounds, terpenes are secondary metabolites of plants that are the best known for their ability to scavenge free radicals $[17,24]$. Phenolic substances are known to be responsible for the antioxidant effect that medicinal plants possess $[25,26]$. The antioxidant effect may be due to its rich content. On the contrary of antioxidant activity, flowers were found to be more effective in anti-inflammatory assay than aerial parts. Flowers and especially yellow flowers are known to be rich in flavonoids [27]. There is strong 
evidence suggesting that flavonoids prevent and reduce inflammation by means of multiple mechanisms. This plant secondary metabolites reduce inflammatory cytokine production, decrease inflammationpromoting cells' recruitment, and modulate inflammatory pathways [28]. Therefore, it is not surprising that flowers were found to be more effective than aerial parts in anti-inflammatory activity assay. Further studies should be conducted to clarify the phytochemical content, flavonoid and phenolic profile of this species.

\section{AUTHOR CONTRIBUTIONS}

Concept : S.G., S.Y.S., T.Ç., C.S.K.; Design: S.G., S.Y.S., T.Ç., C.S.K.; Control: S.G., S.Y.S., T.Ç., C.S.K.; Sources: S.G., S.Y.S., T.Ç., C.S.K.; Materials: S.G., S.Y.S., T.Ç., C.S.K.; Data Collection and/or processing: S.G., S.Y.S., T.Ç., C.S.K.; Analysis and/or interpretation: S.G., S.Y.S., T.Ç., C.S.K.; Literature review: S.G., S.Y.S., T.Ç., C.S.K.; Manuscript writing: S.G., S.Y.S., T.C., C.S.K.; Critical review: S.G., S.Y.S., T.Ç., C.S.K.; Other: S.G., S.Y.S., T.Ç., C.S.K.

\section{CONFLICT OF INTEREST}

The authors declare no conflict of interest.

\section{ETHICS COMMITTEE APPROVAL}

The Ethics Committees of the Faculty of Medicine of Ankara University, Ankara-Turkey approved the study protocol with acceptance number of 26.10.2015/16-695-15.

\section{REFERENCES}

1. Downie, S.R., Katz-Downie, D.S., Watson, M. F. (2000). A phylogeny of the flowering plant family Apiaceae based on chloroplast DNA rpl16 and rpoC1 intron sequences: towards a suprageneric classification of subfamily Apioideae. American Journal of Botany, 87, 273-292. [CrossRef]

2. Olle, M., Bender, I. (2010). The content of oils in umbelliferous crops and its formation. Agronomy Research, 8, 687-696. [CrossRef]

3. Colcimen, N., Arihan, O., Gumusok, S., Kilic, C.S. (2020). Effect of The Opopanax Hispidus Plant's Aerial Parts Extract on Mice Ovary. Selcuk Med J, 36(1), 44-47. [CrossRef]

4. https://www.etymonline.com/search?q=opos - erişim tarihi 13.01.2019

5. Sahranavard, S., Ghafari, S., Mosaddegh, M. (2014). Medicinal plants used in Iranian traditional medicine to treat epilepsy. Seizure, 23, 328-332. [CrossRef] 
6. Adams, M., Schneider, S., Kluge, M., Kessler, M., Hamburger, M. (2012). Epilepsy in the Renaissance: A survey of remedies from $16^{\text {th }}$ and $17^{\text {th }}$ century German herbals. Journal of Ethnopharmacology, 143, 1-13. [CrossRef]

7. Lev, E., Amar, Z. (2008). Fossils of practical medical knowledge from medieval Cairo. Journal of Ethnopharmacology, 119, 24-40. [CrossRef]

8. Javadi, B., Iranshahy, M., Emami, S.A. (2015). Anticancer Plants in Islamic Traditional Medicine, Complementary Therapies for the Body, Mind and Soul. Editör: Marcelo Saad, InTech, DOI: 10.5772/61111[CrossRef]

9. Farzaei, M.H., Farzaei, F., Abdollahi, M., Abbasabadi, Z., Abdolghaffari, A.H., Mehraban, B. (2016). A mechanistic review on medicinal plants used for rheumatoid arthritis in traditional Persian medicine. Journal of Pharmacy and Pharmacology, 68, 1233-1248. [CrossRef]

10. Ahıskalı, M., Arı, C.., Selvi, S. (2012). Edible wild plants and their consumption during winter in a rural village on Kazdağı (Mount Ida). Bocconea, 24, 195-198. [CrossRef]

11. Özgen, U., Kaya, Y., Houghton, P. (2010) Folk medicines in the villages of Ilica District (Erzurum, Turkey). Turkish Journal of Biology, 36, 93-106[CrossRef]

12. Tuzlac1, E., Erol, M.K. (1999). Turkish folk medicinal plants. Part II: Eğirdir (Isparta). Fitoterapia, 70, 593-610. [CrossRef]

13. Sevgi, E., Kızılarslan, Ç. (2013). Bir İsim Çok Bitki - Mayasıl Out. Avrasya Terim Dergisi, 1, 17 29. [CrossRef]

14. Valiakos, E., Marselos, M., Sakellaridis, N., Constantinidis, Th., Skaltsa, H. (2015). Ethnopharmacological approach to the herbal medicines of the "Antidotes" in Nikolaos Myrepsos' Dynameron. Journal of Ethnopharmacology, 163, 68-82. [CrossRef]

15. Amiri, M.S., Joharchi, M.R. (2015). Ethnobotanical knowledge of Apiaceae family in Iran: A review. Avicenna Journal of Phytomedicine, 6, 621-635[CrossRef]

16. Abolhasanzadeh, Z., Ashrafib, H., Badra, P., Azadia, A. (2017). Traditional neurotherapeutics approach intended for direct nose to brain delivery. Journal of Ethnopharmacology, 209, 116123. [CrossRef]

17. Yalçın, C.Ö., Yılmaz Sarıaltın, S., Çiçek Polat, D. (2020). Quantification of phenolic and flavonoid contents and some biological activities of Ornithogalum sigmoideum Freyn \& Sint. $J$ Res Pharm., 24(4), 487-496. [CrossRef]

18. Blois, M.S. (1958). Antioxidant determination by the use of a stable free radical. Nature, 181, 1199-1200. [CrossRef]

19. Anosike, C.A., Obidoa, O., Ezeanyika, L.U. (2012). Membrane stabilization as a mechanism of the anti-inflammatory activity of methanol extract of garden egg (Solanum aethiopicum). Daru, Nov 14, 20(1), 76. doi: 10.1186/2008-2231-20-76. [CrossRef]

20. Gunathilake, K.D.P.P., Ranaweera, K.K.D.S., Rupasinghe, H.P. (2018). In vitro antiinflammatory properties of selected green leafy vegetables. Biomedicines, 6(4), 107. [CrossRef] 
21. Alpınar, K., Özyürek, M., Kolak, U., Güçlü, K., Aras, Ç., Altun, M., Çelik, S. E., Berker, K. I., Bektaşoğlu, B., Apak, R. (2008) Antioxidant Capacities of Some Food Plants Wildly Grown in Ayvalik of Turkey, Food Science and Technology Research, 15, 59-64. [CrossRef]

22. Matejić, J., Džamić, A., Mihajilov-Krstev, T., Ranđelović, V., \& Marin, P. (2015). Antioxidant and antimicrobial potential of Opopanax hispidus (Apiaceae) extracts. Lekovite sirovine, (35), 141-150. [CrossRef]

23. Sarıkürkçü, C., Targan, Ş., Özer, M. S., Tepe, B. (2016) Fatty acid composition, enzyme inhibitory, and antioxidant activities of the ethanol extracts of selected wild edible plants consumed as vegetables in the Aegean region of Turkey, International Journal of Food Properties, 20, 560-572. [CrossRef]

24. Sarialtin, S. Y., Coban, T. (2018). An Overview on the Role of Macular Xanthophylls in Ocular Diseases. Records of natural products, 12(2). [CrossRef]

25. Okur, M. E., Özbek, H., Polat, D. Ç., Y1lmaz, S., \& Arslan, R. (2018). Hypoglycemic activity of Capparis ovata desf. var. palaestina zoh. methanol extract. Brazilian Journal of Pharmaceutical Sciences, 54(3). [CrossRef]

26. Çiçek Polat, D, Yilmaz Sarialtin, S, Çoban, T, Coşkun, M. (2019). Comparison of Walnut (Juglans regia L.) and Olive (Olea europaea L.) Leaves in Terms of Antioxidant and Anti-inflammatory Activity. Adiyaman University Journal of Science, 9 (2), 242-251. [CrossRef]

27. Samuelsson, G., Bohlin, L. (Eds.), 2009, Drugs of Natural Origin - A Treatise of Pharmacognosy, Swedish Pharmaceutical Society, Swedish Pharmaceutical Pressi P.O B1x. 1136, S-111, 81 Stockholm, Sweden

28. Pan, M. H., Lai, C. S., Ho, C. T. (2010). Anti-inflammatory activity of natural dietary flavonoids. Food \& function, 1(1), 15-31. [CrossRef] 